\title{
Sistem Pengendalian Suhu Kelembaban Ruang Sarang Walet Menggunakan Fuzzy Berbasis Mikrokontroler
}

\author{
System Control Swallow Nest Room Temperature Humidity \\ Using Fuzzy Based on Microcontroller
}

\author{
Akhmad Syarif*1, Kusrini ${ }^{2}$, Eko Pramono ${ }^{3}$ \\ 1,2,3 MTI AMIKOM Yogayakarta \\ E-mail: *1akhmadsyarif@students.amikom.ac.id, ${ }^{2}$ kusrini@amikom.ac.id, \\ 3eko_p@amikom.ac.id
}

\begin{abstract}
Abstrak
Sarang walet merupakan tempat memproduksi air liur burung walet yang telah mengeras. Dalam pembuatan sarang walet harus memiliki kriteria-kriteria. Beberapa kriteria tersebut adalah suhu ruangan walet idealnya adalah 26-29 derajat celcius. Kelembaban udara juga berpengaruh terhadap sarang walet. Biasanya untuk mengatasi hal ini terdapat kolam air untuk menampung air pada ruangan. Air yang ada pada kolam tersebut di gunakan untuk mengatur kelembaban udara. Sehingga akan menjadi mirip seperti goa pada umum nya. Tingkat kelembaban dari 70 sampai 90 derajat celcius. Pada Intensitas cahaya 0 lux (gelap total) adalah intensitas cahaya yang disukai oleh Burung Walet untuk bersarang. Untuk bisa mendapatkan suhu dan kelembaban ideal diperlukan system automatis dalam mengontrol suhu dan kelembaban secara realtime. Dengan system automatisasi yang di atur melalui mikrokontroller menggunakan metode Fuzzy Sugeno untuk menghasilkan puteran air pada keran sehingga mempermudah kontrol ruang sarang walet dan juga data suhu serta kelembaban yang di kirim ke database untuk mempermudah monitoring suhu dan kelembaban dari website. Hasilnya adalah dengan penggunaan sistem kontrol suhu dan kelembaban menggunakan metode fuzzy Sugeno didapatkan hasil dengan 3 parameter yaitu suhu, kelembaban dan cahaya adalah $61.11 \%$, sedangkan dengan 2 parameter yaitu suhu dan kelembaban adalah 39.29\% dari 18x percobaan.
\end{abstract}

Kata Kunci-Microcontroller, Arduino, Fuzzy Sugeno, IoT

\begin{abstract}
Swallow's nest is a place to produce hardened swallow birds' saliva. In making swallow nests must have criteria. Some of these criteria are the ideal walet room temperature is 26-29 degrees Celsius. Humidity also affects swallow's nest. Usually to overcome this there is a pool of water to hold water in the room. The water in the pool is used to regulate the humidity of the air. So it will be like a cave in general. Humidity levels from 70 to 90 degrees Celsius. At 0 Lux (total dark) light intensity is the intensity of light favored by Swallow for nesting. To be able to get the ideal temperature and humidity needed an automatic system to control temperature and humidity in real time. With the automation system that is set through a microcontroller using the Fuzzy Sugeno method to produce water spin on the tap making it easier to control swallow nest space and temperature and humidity data sent to the database to facilitate monitoring of temperature and humidity from the website. The result is the use of a temperature and humidity control system using the Sugeno fuzzy method obtained results with 3 parameters namely temperature, humidity and light is $61.11 \%$, while with 2 parameters namely temperature and humidity is $39.29 \%$ from 18x experiments.
\end{abstract}

Keywords-Microcontroller, Arduino, Fuzzy Sugeno, IoT 


\section{PENDAHULUAN}

Burung walet adalah jenis burung yang memiliki ekor panjang, sayap runcing, warna hitam pada bagian tubuh dan juga pada bagian bawah tubuh bewarna coklat. Burung walet biasa hidup sekitaran pantai, dekat pemukiman, gua atau ruangan besar yang kosong, gelap dan lembab. Burung walet sering menempel pada dinding tembok, atap atau sekat-sekat ruangan. Dengan hidup berkelompok burung walet membuat sarang dari air liur mereka yang telah mengkeras saat kering. Habitat burung walet banyak berada di daerah Asia Tenggara.

Faktor yang mempengaruhi produksi dari sarang Burung Walet salah satunya yaitu faktor lingkungan tempat tinggal. Kondisi dari habitat buatan mereka harus dikondisikan sesuai dengan kondisi tempat tinggal aslinya seperti di dalam gua yaitu dengan mengatur suhu, kelembaban dan instensitas cahaya. Intensitas cahaya yang Burung Walet sukai sebagai sarang atau untuk tempat tinggal adalah 0 lux (artinya adalah gelap total) [1]. Suhu maksimal sarang walet yaitu berkisar 26-28 ${ }^{\circ} \mathrm{C}$ dengan kisaran kelembaban antara 85-98\% [2]. Sementara penelitian lain menyebutkan suhu pada sarang walet diantara $27-29^{\circ} \mathrm{C}$ dengan kelembaban 70-95\% [3]. Jika lingkungan sarang walet bisa dijaga dari kisaran optimum layak nya sebuah gua tempat tinggal burung walet seperti yang dijelaskan diatas maka produksi sarang burung walet akan menjadi maksimal [4].

Alat elektronika digital yang mempunyai fitur input dan output yang bisa dikontrol menggunakan suatu bahasa program yang mana bisa ditulis dan dihapus sesuai keinginan adalah Mikrokontroler [5]. Penggunaan Mikrokontroler sebagai pengendali suhu dan kelembaban didalam Ruangan sarang walet dengan menyesuaikan dengan Suhu dan kelembaban yang diinginkan [6]. IoT sangat terkenal dengan teknologi yang ada pada dirinya sendiri, yang mana dapat dihubungkan dengan setiap alat yang telah dikenali dengan cara dikontrol menggunakan sebuah komputer yang terhubung melalui sebuah jaringan entah itu wireless yang mana bisa dengan mudah berbagi informasi dari sebuah hardware. Karena, penting untuk setiap orang mengetahui sebuah infromasi [7]. Mikrokontroler akan banyak membawa dampak beberapanya adalah kemudahan dan efektivitas kerja. Contohnya bagi pegawai industri dan perkantoran menengah akan merasa sangat bermanfaat jika ada sistem kontrol untuk suhu ruangan pada proses kegiatan bekerja dan menjadi efisien [8].

Penelitian ini menggunakan suhu 26-29 $\mathrm{C}$ dan kelembaban 70-98\%. Dari kesimpulan suhu yang digunakan $26-29^{\circ} \mathrm{C}$, dikarenakan dari keseluruhan penelitian - penelitian sebelumnya yaitu $26-28^{\circ} \mathrm{C}$ dan $27-29^{\circ} \mathrm{C}$ [2][3]. Untuk kelembaban $70-98 \%$ karena rentang yang besar untuk menstabilkan suhu ruangan dan disetujui oleh pihak sarang walet.

Penelitian untuk perancangan sistem yang mengontrol atau monitor suhu dan kelembaban ruangan pada sarang burung walet ini bertujuan untuk mempermudah pihak sarang walet dalam mengkontrol atau monitor suhu dan kelembaban ruangan sarang walet.

\section{METODE PENELITIAN}

Sebuah perancangan merupakan proses yang sangat penting dalam membuat suatu sistem ataupun untuk ke langkah penelitian selanjutnya, karena dengan perencanaan sistem tersebut diharapkan mendapatkan hasil yang baik dan maksimal. Peneliti membuat perancangan suatu sistem baru agar berfungsi sebagaimana yang diharapkan dengan berbasis teknologi otomatis mengunakan algoritma Fuzzy Sugeno dan terbagi dari beberapa diagram untuk masing-masing komponen yang terintegrasi menjadi sebuah alat [9].

\subsection{Sistem Kontrol}

Penelitian ini memiliki parameter yang digunakan berupa suhu, kelembaban dan cahaya. Arduino akan memberikan puteran pada keran untuk membuka aliran air. Sistem kontrol suhu dan kelembaban ruangan sarang walet berkerja sebagai berikut: 
1) Mengukur nilai suhu, kelembaban dan cahaya.

2) Menkonversi nilai suhu, kelembaban dan cahaya menjadi nilai keanggotaan setiap daerah masing-masing menggunakan fuzzifikasi.

3) Inferensi adalah penerapan suatu aturan hingga menghasilkan nilai puteran keran agar tidak keluar dari pada pada rentang nilai puteran keran yang diinginkan berdasarkan rule yang telah ditetapkan.

4) Defuzzifikasi untuk mengubah output fuzzy menjadi nilai sebenarnya untuk menentukan berapa puteran keran pada kondisi suhu, kelembaban dan cahaya tertentu.

Arduino menggunakan servo untuk memutar keran sesuai hasil output dari defuzzifikasi. Penelitian ini menggunakan metode logika fuzzy (Fuzzy Logic Controller) sebagai sistem control yang digunakan. Logika fuzzy pada prinsipnya menggunaka pengambil keputusan logika fuzzy (Fuzzy Inference System) sebagai metode pengontrol. Dalam mendefinisikan suatu himpunan fuzzy, rancangan kontroller logika fuzzy adalah merupakan pengembangan aspek dengan logika fuzzy. Pada prinsipnya kontroler logika fuzzy adalah merupakan controller yang mengubah dari suatu kontrol linguistic ke dalam kontrol otomatis [10]. Sistem fuzzy yang terdapat pada mikrokontroler arduino akan memberikan sebuah mesin dengan pola pikir cerdas yang dapat menentukan sebuah keputusan [11]. Gambar konfigurasi kontroller logika fuzzy bisa dilihat pada Gambar 1.

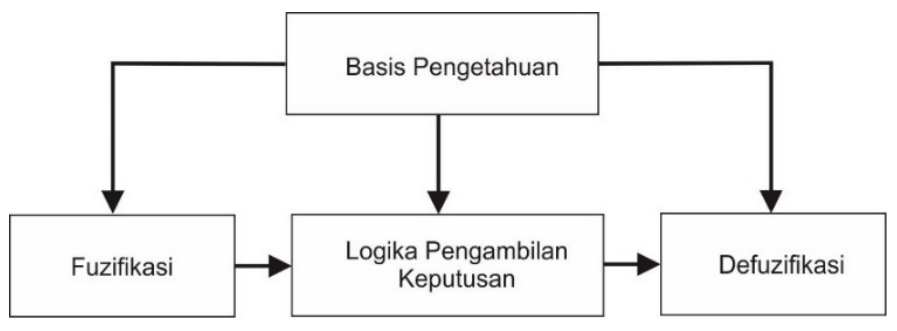

Gambar 1. Konfigurasi Kontroller Logika Fuzzy

Fuzzy logic controller pada umumnya memiliki 4 bagian utama yang diasumsikan sebagai sistem kontroler loop tertutup seperti yang ditunjukan pada Gambar 1. Empat bagian utama yang disebutkan tadi adalah sebagai berikut:

\subsubsection{Fuzzifikasi}

Fuzzifikasi merupakan sebuah proses pengubahan masukan menjadi bentuk fuzzy input yang awalnya bersifat crisp input (pasti). Beberapa fungsi fuzzifikasi adalah berikut [12]: a.) pengukuran suatu variable nilai masukan, b.) menggambarkan masukan rentang nilai ke dalam himpunan semesta, c.) menggunakan fungsi fuzzifikasi mengubah data input menjadi suatu yang sesuai nilai linguistik dan menjadi suatu label dari suatu fuzzy himpunan. Fungsi keanggotaan menunjukan daerah-daerah titik-titik data input ke dalam suatu nilai keanggotaan (derajat keanggotaan) dengan interval adalah 0-1 yang digambarkan dengan suatu kurva [12]. Gambar 2 merupakan gambaran fungsi derajat keanggotaan suhu yang digunakan pada penelitian ini. Sedangkan untuk gambaran fungsi derajat keanggotaan kelembaban tersaji pada gambar 3 dan gambar 4 merupakan gambaran fungsi derajat keanggotaan cahaya.

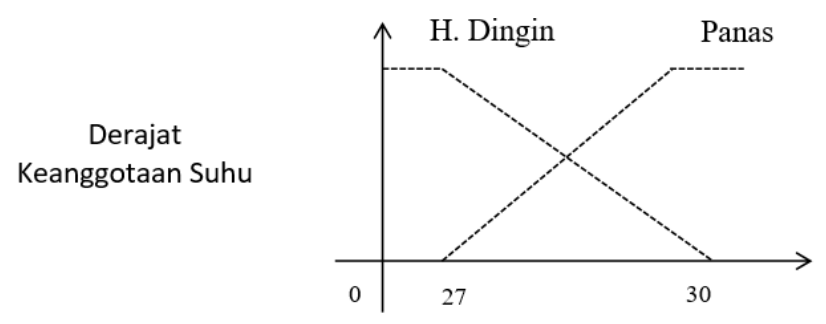

Gambar 2. Fungsi Derajat Keanggotaan Suhu 
Citec Journal, Vol. 6, No. 2, Juli 2019

ISSN: 2354-5771

Dengan rumus derajat keanggotaan suhu yang dapat dilihat pada persamaan 1 dan 2.

$$
\begin{aligned}
& \text { H. Panas }=\left\{\begin{array}{c}
1 ; x \leq 27 \\
\frac{(30-x)}{(30-27)} ; 27 \leq x \leq 30 \\
0 ; x \geq 30
\end{array}\right. \\
& \text { Panas }=\left\{\begin{array}{c}
0 ; x \leq 27 \\
\frac{(x-27)}{(30-27)} ; 27 \leq x \leq 30 \\
1 ; x \geq 30
\end{array}\right.
\end{aligned}
$$

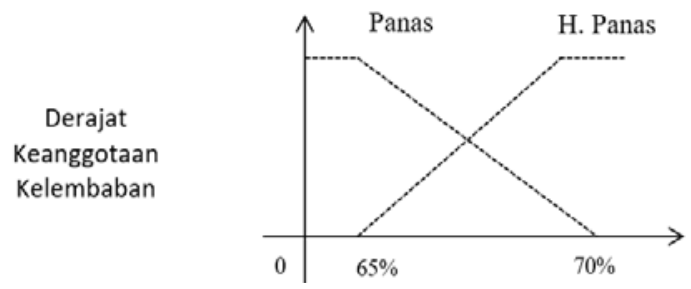

Gambar 3. Fungsi Derajat Keanggotaan Kelembaban

Dengan rumus derajat keanggotaan kelembaban yang dapat dilihat pada persamaan 3 dan persamaan 4.

$$
\begin{gathered}
\text { Panas }=\left\{\begin{array}{c}
1 ; x \leq 0,65 \\
\frac{(0,7-x)}{(0,7-0,65)} ; 0,65 \leq x \leq 0,7 \\
0 ; x \geq 0,7
\end{array}\right. \\
\text { H.Panas }=\left\{\begin{array}{c}
0 ; x \leq 0,65 \\
\frac{(x-0,65)}{(0,7-0,65)} ; 0,65 \leq x \leq 0,7 \\
1 ; x \geq 0,7
\end{array}\right.
\end{gathered}
$$

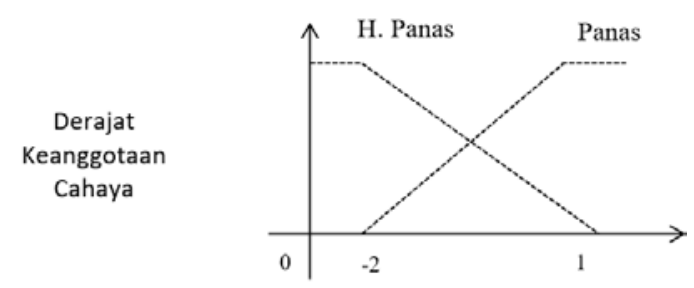

Gambar 4. Fungsi Derajat Keanggotaan Cahaya

Dengan rumus derajat keanggotaan cahaya yang dapat dilihat pasa persamaan 5 dan 6 .

$$
\begin{gathered}
\text { H.Panas }=\left\{\begin{array}{c}
1 ; x \leq-2 \\
\frac{(1-x)}{(1-(-2))} ;-2 \leq x \leq 1 \\
0 ; x \geq 1
\end{array}\right. \\
\text { Panas }=\left\{\begin{array}{c}
0 ; x \leq-2 \\
\frac{(x-(-2))}{(1-(-2))} ;-2 \leq x \leq 1 \\
1 ; x \geq 1
\end{array}\right.
\end{gathered}
$$




\subsubsection{Basis Pengetahuan}

Basis pengetahuan berisi tentang pengetahuan sebuah sistem dan kumpulan tujuan dalam pengontrolan. Basis pengetahuan berguna untuk merumuskan perilaku dari kontroler untuk mencapai jenis pengontrolan yang diinginkan [10]. Basis pengetahuan yang digunakan pada penelitian ini merupakan bagian-bagian yang menjelaskan suatu masukan dan keluaran himpunan fuzzy, ditunjukkan pada Tabel 1.

Tabel 1. Basis Pengetahuan

\begin{tabular}{|l|l|l|l|l|l|l|c|}
\hline \multicolumn{2}{|c|}{ Suhu } & \multicolumn{2}{c|}{ Kelembaban } & \multicolumn{2}{c|}{ Cahaya } & \multicolumn{2}{c|}{ Keran Di Buka } \\
\hline $\begin{array}{l}\text { Suhu } \\
27^{\circ}\end{array}$ & $\begin{array}{l}\text { Hampir } \\
\text { Panas }\end{array}$ & $\begin{array}{l}\text { Kelembaban } \\
<=70 \%\end{array}$ & $\begin{array}{l}\text { Hampir } \\
\text { Panas }\end{array}$ & $\begin{array}{l}\text { Cahaya } \\
>=2 \text { lux }\end{array}$ & $\begin{array}{l}\text { Hampir } \\
\text { Panas }\end{array}$ & $\begin{array}{l}\text { Dibuka } \\
<=45^{\circ}\end{array}$ & Kecil \\
\hline $\begin{array}{l}\text { Suhu } \\
30^{\circ}\end{array}$ & Panas & $\begin{array}{l}\text { Kelembaban } \\
<=65 \%\end{array}$ & Panas & $\begin{array}{l}\text { Cahaya } \\
>=1 \text { lux }\end{array}$ & Panas & $\begin{array}{l}\text { Dibuka } \\
<=90^{\circ}\end{array}$ & Besar \\
\hline
\end{tabular}

\subsubsection{Logika Pengambilan Keputusan}

Berdasarkan pengetahuan pakar, logika pengambilan keputusan memiliki sekumpulan aturan pada fuzzy yang berisi kumpulan-kumpulan kondisi seperti 'IF-THEN'. Dari bentuk kondisi fuzzy, kumpulan-kumpulan kontrol aturan fuzzy adalah sebuah kondisi aturan dasar kontrol logika fuzzy [12]. Suatu hubungan fuzzy memiliki hubungan dengan setiap aturan yang ada di basis pengetahuan. Di dalam fungsi implikasi memiliki bentuk umum sebuah aturan yaitu IF $\mathrm{x}$ is A THEN $\mathrm{y}$ is B [12]. Fungsi implikasi MAX-MIN adalah yang umum digunakan. Kontrol aturan fuzzy memiliki kegunaan yaitu untuk menjabarkan kondisi bentuk fuzzy. Aturan kontrol fuzzy memiliki rancangan seperti berikut:

1. Pemilihan Variabel Input dan Output

Acuan utama aturan kontrol fuzzy untuk menghasilkan sinyal atur secara umum nilai error dan perubahan error ( $\Delta$ Error). Nilai $\Delta$ Error didapatkan dari Error Baru dikurangi Error Lama. Sedangkan nilai Error adalah Set Point dikurangi Present Value.

2. Penurunan Kontrol Aturan Fuzzy

Dengan cara mengkoreksi keluaran air dari pada keadaan yang diharapkan untuk menurunankan kontrol aturan menggunakan Metode Macvicar-Whelan matrix yang sudah umum dan sering digunakan. Metode Macvicar-Whelan adalah metode yang bekerja untuk menyempurnakan suatu kontrol aturan dan menemukan sebuah pola umum yang berhubungan diantara perubahan error ( $\Delta$ Error) dan Error. Tabel keputusan MacvicarWhelan berguna untuk memberikan tabel keputusan sinyal atur terhadap penurunan aturan kontrol secara lengkap. Tabel dibawah ini secara maksimum adalah untuk menghasilkam sejumlah kontrol aturan. Kontrol logika fuzzy yang menggunakan suatu perubahan error dan suatu masukan error berlaku untuk pola ini. Tabel 2 menunjukan fuzzy control aturan [13].

Tabel 2. Kontrol aturan fuzzy Macvicar-Whelan matriks

\begin{tabular}{|c|c|c|c|c|c|c|c|}
\hline & NB & NM & NS & $\mathrm{ZO}$ & PS & $\mathrm{PM}$ & PB \\
\hline NB & NB & NB & $\mathrm{NB}$ & NB & NM & NS & $\mathrm{ZO}$ \\
\hline $\mathrm{NM}$ & NB & NB & NB & $\mathrm{NM}$ & NS & $\mathrm{ZO}$ & PS \\
\hline NB & NB & NB & NM & NS & $\mathrm{ZO}$ & PS & PM \\
\hline $\mathrm{ZO}$ & NB & NM & NS & $\mathrm{ZO}$ & PS & $\mathrm{PM}$ & PB \\
\hline PS & NM & NS & $\mathrm{ZO}$ & PS & $\mathrm{PM}$ & PB & PB \\
\hline $\mathrm{PM}$ & NS & $\mathrm{ZO}$ & PS & $\mathrm{PM}$ & PB & PB & PB \\
\hline PB & $\mathrm{ZO}$ & PS & $\mathrm{PM}$ & PB & PB & PB & PB \\
\hline
\end{tabular}




\subsubsection{Defuzzifikasi}

Defuzzifikasi adalah tahapan untuk seluruh perhitungan output yang berupa masih bernilai fuzzy menjadi sebuah hasil yang lebih pasti dan spesifik (crisp value) ditentukan berdasarkan fungsi keanggotaan. Terdapat beberapa metode dapat digunakan, salah satunya adalah center of area (COA). Pada metode ini diperoleh solusi nilai crips dengan cara pada daerah fuzzy diambil titik pusat (z). Pada umumnya dirumuskan sebagai seperti pada rumusan 10 [12] .

$$
Z=\frac{\sum_{j=1}^{n} Z j u(Z j)}{\sum_{j=1}^{n} \mu(Z j)}
$$

Dengan:

$\mathrm{Z} \quad=$ Solusi yang diberikan dari hasil fuzzy atau keputusan akhir

$\mathrm{Zj} \quad=$ Rentang suatu himpunan semesta $\mathrm{Z}$

$\mu(Z) \quad=$ Nilai-nilai keanggotaan dari setiap solusi fuzzy

\section{HASIL DAN PEMBAHASAN}

\subsection{Rancangan User Interface Website}

Halaman dashboard dari system ini menampilkan kondisi ruang sarang walet. Halaman ini memonitoring 4 bagian yaitu suhu, kelembaban, cahaya dan putaran keran yang terbuka hasil dari fuzzy yang ada pada ruangan sarang walet yang didapat dari arduino. Sistem aplikasi ini secara otomatis melakukan memonitoring berdasarkan data yang dikirimkan oleh arduino ke dalam database yang telah ditentukan, selanjutnya akan ditampilkan pada sebuah halaman website. Contoh halaman website monitoring suhu dan kelembaban ruang sarang walet pada Gambar 5.

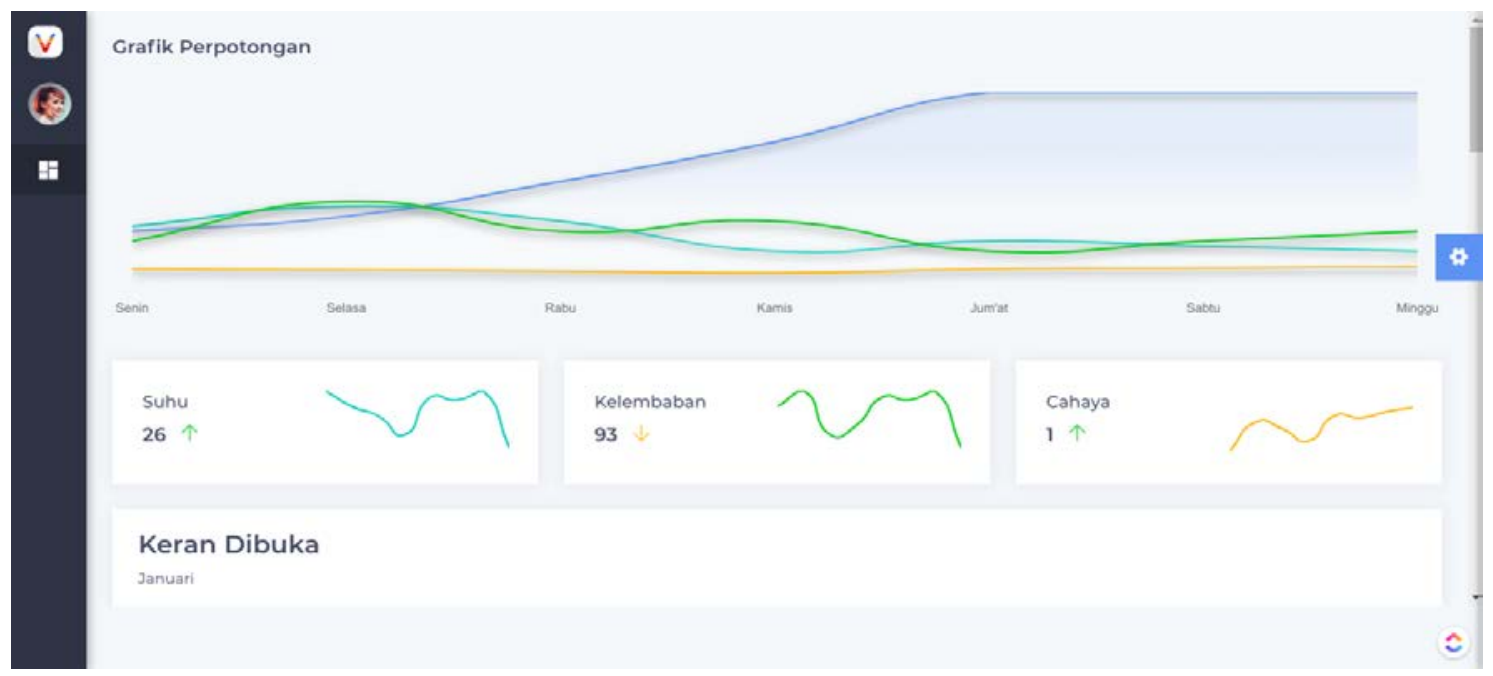

Gambar 5. Halaman Website Utama Monitoring

\subsection{Rancangan Sistem Kontroler}

Penerapan sistem monitoring dan kontrol suhu serta kelembaban didalam ruang sarang walet adalah titik fokus dari penelitian ini. Untuk melakukan monitoring dan kontrol suhu serta kelembaban yang diperlukan dalam system, mekanik ini terdiri dari servo untuk membuka seberapa besar keran air, LDR sensor sebagai sensor cahaya untuk mengambil nilai cahaya pada sarang wallet. Sensor DHT11 digunakan untuk sensor kelembaban dan suhu untuk mengambil nilai kelembaban dan suhu pada sarang wallet. Modul ESP8266 sebagai wifi untuk mengirimkan 
data suhu, kelembaban dan cahaya ke dalam database yang nanti akan ditampilkan pada halaman website. LCD sebagai menampilkan data suhu, kelembaban, cahaya dan hasil fuzzy. Gambar rancangan mikrokontroler bisa di lihat pada Gambar 6.

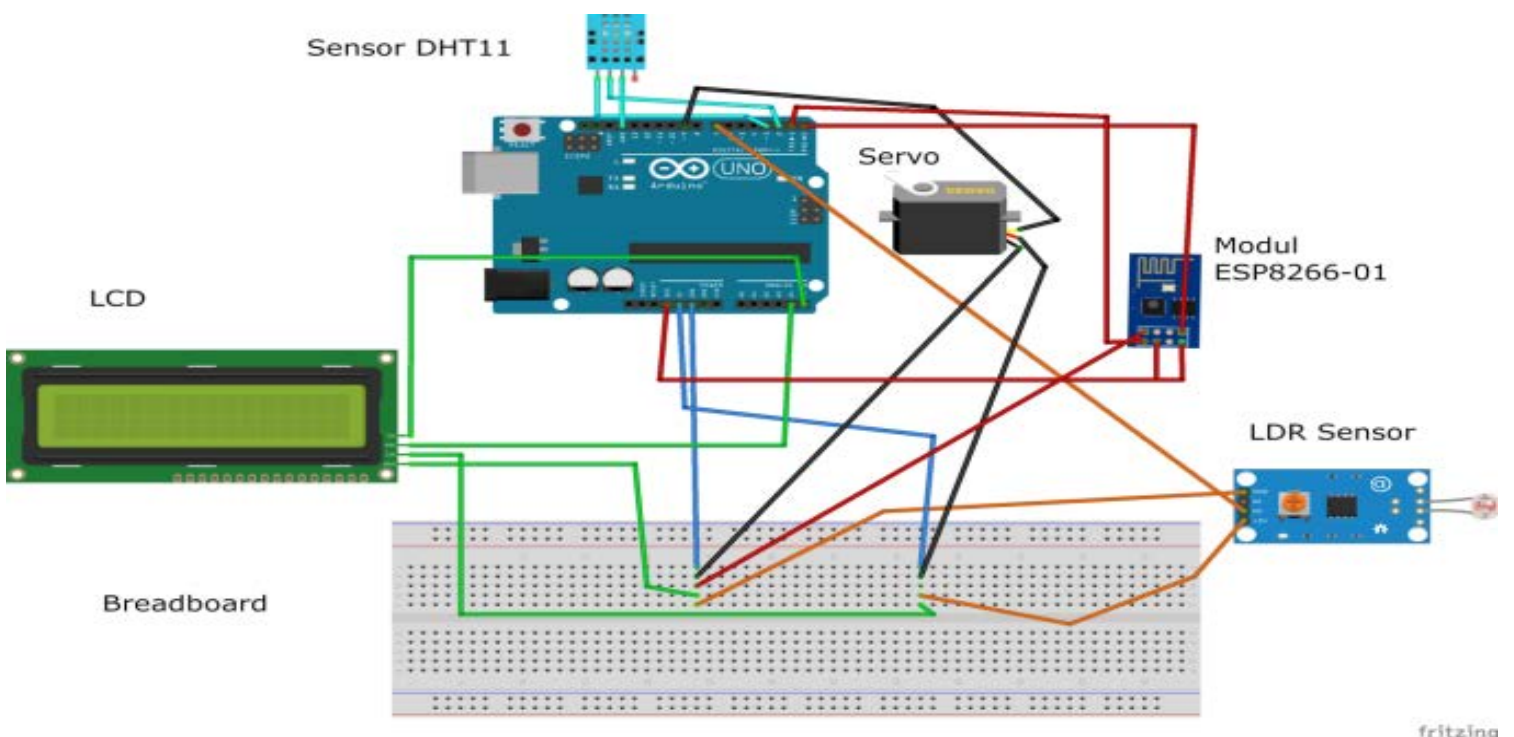

Gambar 6. Desain sistem kontroler

Gambar 6 adalah gambaran secara keseluruhan bentuk sistem kontrol suhu dan kelembaban ruang sarang walet yang dirancang. Memiliki 1 buah sensor DHT11. Sensor DHT11 berfungsi untuk menangkap nilai kelembaban dan suhu yang ada didalam ruangan sarang wallet. Sebuah sensor $L D R$ untuk menangkap nilai cahaya yang ada pada ruangan sarang wallet. Sebuah servo untuk mengendalikan buka tutup keran dan Modul ESP8266-01 berguna untuk menghubungkan ke koneksi internet untuk mengirim data suhu, kelembaban dan cahaya ke website untuk dimonitoring dan dilakukan fuzifikasi.

\subsection{Pengujian Sistem Kontroler}

Pengujian berguna untuk melihat performa sistem ketika suhu, kelembaban dan cahaya dalam kondisi tertentu. Pengujian dilakukan dengan 2x yaitu pada 3 parameter suhu, kelembaban dan cahaya, dan juga pada 2 parameter saja yaitu suhu dan kelembaban. Yang mana untuk mengetahui apakah parameter cahaya mempengaruhi dalam kontrol sistem untuk suhu dan kelembaban. Untuk hasil pengujian respon sistem dengan 3 parameter yaitu suhu, kelembaban, dan cahaya terangkum pada tabel 2. Hasil pengujian respon sistem dengan 2 parameter yaitu suhu dan kelembaban terangkum pada tabel 3.

Tabel 2. Respon Sistem Mengunakan 3 Parameter

\begin{tabular}{|l|c|c|c|c|c|c|c|c|c|c|}
\hline No & Suhu & $\begin{array}{c}\text { Ket } \\
\text { Suhu }\end{array}$ & Kelembaban & $\begin{array}{c}\text { Ket } \\
\text { Kelembaban }\end{array}$ & Cahaya & $\begin{array}{c}\text { Ket } \\
\text { Cahaya }\end{array}$ & Harapan & Kenyataan & $\begin{array}{c}\text { Ket. } \\
\text { Kenyataan }\end{array}$ & Ket. \\
\hline 1 & 33 & panas & 67 & hampir panas & 0 & $\begin{array}{c}\text { hampir } \\
\text { panas }\end{array}$ & Besar & 48 & Besar & benar \\
\hline 2 & 22 & dingin & 40 & panas & 1 & panas & Besar & 63 & Besar & benar \\
\hline 3 & 28 & $\begin{array}{c}\text { hampir } \\
\text { panas }\end{array}$ & 62 & panas & 2 & panas & Besar & 53 & Besar & benar \\
\hline 4 & 34 & panas & 73 & dingin & -1 & $\begin{array}{c}\text { hampir } \\
\text { panas }\end{array}$ & Kecil & 64 & Besar & salah \\
\hline 5 & 41 & panas & 68 & hampir panas & -2 & $\begin{array}{c}\text { hampir } \\
\text { panas }\end{array}$ & Kecil & 60 & Besar & salah \\
\hline
\end{tabular}


Citec Journal, Vol. 6, No. 2, Juli 2019

ISSN: 2354-5771

\begin{tabular}{|l|c|c|c|c|c|c|c|c|c|c|}
\hline No & Suhu & $\begin{array}{c}\text { Ket } \\
\text { Suhu }\end{array}$ & Kelembaban & $\begin{array}{c}\text { Ket } \\
\text { Kelembaban }\end{array}$ & Cahaya & $\begin{array}{c}\text { Ket } \\
\text { Cahaya }\end{array}$ & Harapan & Kenyataan & $\begin{array}{c}\text { Ket. } \\
\text { Kenyataan }\end{array}$ & Ket. \\
\hline 6 & 17 & dingin & 66 & hampir panas & 1 & panas & Kecil & 75 & Besar & salah \\
\hline 7 & 26 & dingin & 32 & panas & -2 & $\begin{array}{c}\text { hampir } \\
\text { panas }\end{array}$ & Kecil & 61 & Besar & salah \\
\hline 8 & 30 & panas & 63 & hampir panas & 0 & $\begin{array}{c}\text { hampir } \\
\text { panas }\end{array}$ & Besar & 18 & Kecil & salah \\
\hline 9 & 29 & $\begin{array}{c}\text { hampir } \\
\text { panas }\end{array}$ & 57 & panas & 4 & panas & Besar & 59 & Besar & benar \\
\hline 10 & 41 & panas & 52 & panas & -4 & dingin & Besar & 62 & Besar & benar \\
\hline 11 & 16 & dingin & 75 & dingin & 8 & panas & Kecil & 71 & Besar & salah \\
\hline 12 & 29 & $\begin{array}{c}\text { hampir } \\
\text { panas }\end{array}$ & 72 & dingin & -1 & $\begin{array}{c}\text { hampir } \\
\text { panas }\end{array}$ & Kecil & -300 & Mati & salah \\
\hline 13 & 27 & $\begin{array}{c}\text { hampir } \\
\text { panas }\end{array}$ & 67 & hampir panas & 5 & panas & Besar & 58 & Besar & benar \\
\hline 14 & 32 & panas & 65 & panas & 6 & panas & Besar & 57 & Besar & benar \\
\hline 15 & 39 & panas & 76 & dingin & 9 & panas & Besar & 63 & Besar & benar \\
\hline 16 & 27 & $\begin{array}{c}\text { hampir } \\
\text { panas }\end{array}$ & 55 & panas & 9 & panas & besar & 61 & Besar & benar \\
\hline 17 & 28 & $\begin{array}{c}\text { hampir } \\
\text { panas }\end{array}$ & 66 & hampir panas & 0 & hampir & kecil & 70 & Besar & salah \\
\hline 18 & 32 & panas & 63 & panas & 4 & panas & besar & 54 & Besar & benar \\
\hline
\end{tabular}

Tabel 3. Respon Sistem Mengunakan 2 Parameter

\begin{tabular}{|l|c|c|c|c|c|c|c|c|}
\hline No & Suhu & Ket Suhu & Kelembaban & $\begin{array}{c}\text { Ket } \\
\text { Kelembaban }\end{array}$ & Diharapkan & Kenyataan & $\begin{array}{c}\text { Kenyataan } \\
\text { ket }\end{array}$ & Ket. \\
\hline 1 & 33 & panas & 67 & hampir panas & besar & 32 & kecil & salah \\
\hline 2 & 22 & dingin & 40 & panas & kecil & 60 & besar & salah \\
\hline 3 & 28 & hampir panas & 62 & panas & besar & -38 & mati & salah \\
\hline 4 & 34 & panas & 73 & dingin & kecil & 58 & besar & salah \\
\hline 5 & 41 & panas & 68 & hampir panas & kecil & 53 & besar & salah \\
\hline 6 & 17 & dingin & 66 & hampir panas & kecil & 82 & besar & salah \\
\hline 7 & 26 & dingin & 32 & panas & kecil & 56 & besar & salah \\
\hline 8 & 30 & panas & 63 & hampir panas & besar & 225 & besar & benar \\
\hline 9 & 29 & hampir panas & 57 & panas & besar & 44 & kecil & salah \\
\hline 10 & 41 & panas & 52 & panas & besar & 42 & kecil & salah \\
\hline 11 & 16 & dingin & 75 & dingin & mati & 88 & besar & salah \\
\hline 12 & 29 & hampir panas & 72 & dingin & kecil & -15 & mati & salah \\
\hline 13 & 27 & hampir panas & 67 & hampir panas & kecil & 59 & besar & salah \\
\hline 14 & 32 & panas & 65 & panas & besar & -45 & mati & salah \\
\hline 15 & 39 & panas & 76 & dingin & kecil & 59 & besar & salah \\
\hline 16 & 27 & hampir panas & 55 & panas & besar & 53 & besar & benar \\
\hline 17 & 28 & hampir panas & 66 & hampir panas & kecil & 70 & besar & salah \\
\hline 18 & 32 & panas & 63 & panas & besar & -72 & mati & salah \\
\hline
\end{tabular}

Hasil 2 pengujian tersebut ketika menggunakan parameter cahaya ada 10 percobaan yang sesuai harapan dari 18 data percobaan dengan akurasi 61.11\%. Ketika tidak menggunakan parameter cahaya ada 2 percobaan yang sesuai harapan dari 18 data percobaan dengan akurasi $39.29 \%$. 


\subsection{Pengujian Fungsional Sistem}

Pada tahap ini melakukan simulasi pada system yang telah dibangun untuk pengambilan keputusan yang akan dilakukan. Dengan menggunakan arduino untuk mengabil nilai suhu, kelembaban dan cahaya kepada sistem fuzzy Sugeno. Data suhu, kelembaban dan cahaya yang diambil setiap 5 menit. Setiap data suhu, kelembaban dan cahaya didapat, program akan secara langsung melakukan pengiriman nilai (data suhu, kelembaban dan cahaya) ke sebuah database. Dengan bantuan modul wi-fi ESP8266 arduino yang telah terkoneksi pada wifi maka arduino akan mengirimkan data ke database. Pada website akan melakukan pembaruan data setiap mendapatkan data baru dari sensor secara realtime. Ketika kondisi suhu, kelembaban dan cahaya tidak dalam kondisi ideal, sistem akan mengambil keputusan untuk membuka keran sesuai dari derajat keran yang dibuka hasil dari fuzzy Sugeno.

\section{KESIMPULAN}

Kesimpulan pada penelitian ini bahwa penggunaan IoT dengan metode Sugeno untuk kontroling suhu dan kelembaban pada ruangan sarang walet dapat dilakukan. Hasil yang didapat ketika dilakukan simulasi sistem menunjukkan bahwa proses monitoring dapat berjalan dengan baik. Tujuan dari penelitian ini diharapkan bisa memudahkan dalam memantau serta mengontrol suhu dan kelembaban ruang sarang walet tanpa perlu pergi atau berada di lokasi dengan adanya halaman website yang telah disediakan secara realtime dalam melakukan pemantauan tersebut. Pebandingan dilakukan terhadap penelitian sebelumnya yang mana kontroling suhu dan kelembaban sarang walet menggunakan arduino nano dengan monitor pada LCD dan tanpa menggunakan metode algoritma seperti pada penelitian ini. Kelebihan pada system yang dibuat peneliti adalah dengan adanya penerapan IoT dalam mengirim data dari mikrokontroler ke database website secara realtime serta didukung dengan algoritma pengambilan keputusan Fuzzy Sugeno untuk menentukan keputusan seberapa besar derajat keran yang akan dibuka yang mana diharapkan untuk menjaga suhu, kelembaban dan cahaya pada sarang walet tetap optimal. Dengan adanya IoT diharapkan sistem benar-benar dapat diakses secara online bukan hanya sekedar jaringan lokal agar dapat dipantau dimanapun.

\section{SARAN}

Saran yang diberikan peneliti untuk penelitian selanjutnya adalah penambahan metode yang akurasi lebih akurat, sistem notifikasi berupa pesan jika suhu dalam beberapa menit masih keadaan tidak normal, bot pada sistem aplikasi chat untuk mempermudah monitoring dan pengiriman pesan. Dan juga diperlukan nya program yang bisa mengatur rule dan nilai range fuzzy secara fleksibel.

Kendala peneliti ketika melakukan penelitian ini salah satunya adalah terbatasnya alat mekanik kualitas lebih bagus untuk memaksimalkan sistem ini. Hal ini menyebabkan proses perangkaian alat menjadi terhambat dan kurang maksimal.

\section{DAFTAR PUSTAKA}

[1] Francis, C. M., 1987, The Management of Edible Bird's Nest Caves in Sabah Wildlife Section, Sabah Forest Department, Sabah.

[2] Mardiastuti, A., Mulyani, Y. A., Sugarjito, J., Ginoga, L. N., Maryanto, I., Nugraha, A., Ismail., 1998, Teknik pengusahaan Burung Walet rumah, pemanenan sarang, dan penanganan pasca panen, Laporan Riset Unggulan Terpadu IV., Kantor Menteri Negeri Riset dan Teknologi, Dewan Riset Nasional, Jakarta. 
Citec Journal, Vol. 6, No. 2, Juli 2019

[3] Sofwan, A. dan P. Winarso, 2005, Rancang Bangun Sistem Pengendali Suhu dan Kelembaban udara pada rumah Burung Walet berbasis mikrokontroler AT89C51, ISBN: 979-756-061-6.

[4] Ayuti, T., Garnida, D., Asmara, I. Y., 2016, Identifikasi Habitat dan Produksi Sarang Burung Walet (Collocalia fuciphaga) Di Kabupaten Lampung Timur, Students e-Journal UPPAD, No. 4, Vol. 5.

[5] Kadir, A., 2013, Panduan Praktis MempelajariAplikasi Mikrokontro-ler dan Pemrograman Mengguna-kan Arduino, Andi Offset, Yogyakarta.

[6] Subandi, E. S., Rahman, A. F. S. R., Asni B, A., 2019, Sistem Pengatur Suhu Dan Kelembaban Sarang Burung Walet Menggunakan Arduino Nano, JTE UNIBA, No. 2, Vol. 3, Hal. 13 - 18.

[7] Fahmi, N., Huda, S., Sudarsono, A., Al Rasyid, M. U. H., 2017, Fuzzy Logic for and Implementation Environment Health Monitoring System Based on Wireless Sensor Network, JTEC Journal, No. 2, Vol 4.

[8] Prihatmoko, D., 2016, Perancangan dan Implementasi Pengontrol Suhu Ruangan Berbasis Mikrokontroller Arduino Uno, Jurnal Simetris, No. 1, Vol. 7, Hal. 117 - 122

[9] Mulyana, I. E., Kharisman, R., 2014, Perancangan Alat Peringatan Dini Bahaya Banjir dengan Mikrokontroler Arduino Uno R3, Citec Jurnal, No. 3, Vol. 1, Hal.

[10] Hamdani, D. R., 2009, Kendali Kecepatan Robot Beroda Menggunakan Fuzzy Logic Berbasis Mikrokontroller ACR ATMEGA8535, Skrisi, Universitas Mercu Buana, Jakarta.

[11] Farmadi, A., Nugrahadi, D. T., Indriani, F., Soesanto, O., 2017, System Fuzzy Logic Tertanam Pada Mikrokontroler Untuk Penyiraman Tanaman Pada Rumah Kaca, KLIK Journal, No. 2, Vol. 4, Hal. 223 - 232

[12] Kusumadewi, S., Purnomo, H., 2013, Aplikasi Logika Fuzzy untuk Pendukung, Graha Ilmu, Yogyakarta.

[13] Heliadi, G. G., Kirom, M. R., Suhendi, A., 2018, Monitoring Dan Kontrol Nutrisi Pada Sistem Hidroponik NFT Berbasis Konduktivitas Elektrik, e-Proceeding of Engineering, No. 1, Vol. 5, Hal. 885 - 893 